\title{
Kebijakan Merdeka Belajar dan Implementasi Nilai-Nilai Pancasila Pada Era Tatanan Baru
}

\section{Prof. Dr. Nunuk Suryani, M.Pd}

Sekretaris Direktorat Jendral Guru dan Tenaga Kependidikan Kemendikbud nunuksuryani@fkip.uns.ac.id

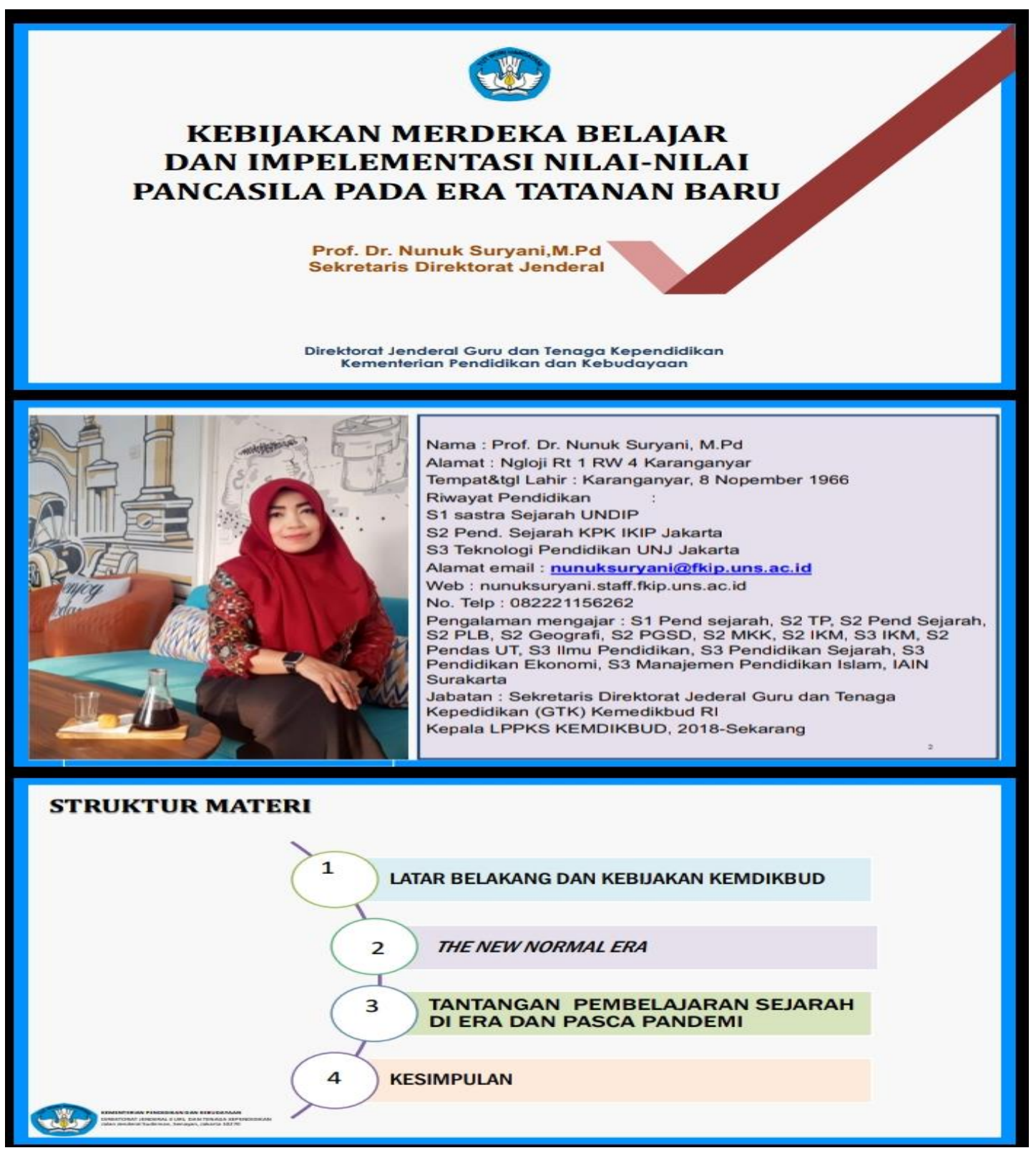

Social, Humanities, and Education Studies (SHEs): Conference Series https://jurnal.uns.ac.id/shes

p-ISSN 2620-9284 e-ISSN 2620-9292

This work is licensed under a Creative Commons Attribution-ShareAlike 4.0 International License. 


\section{Latar Belakang dan Kebijakan Kemendikbud}

\section{Analogi WhatsApp}

\section{SENT}

- Program terlaksana.

- Anggaran terserap.
(D) DOUBLE CHECK

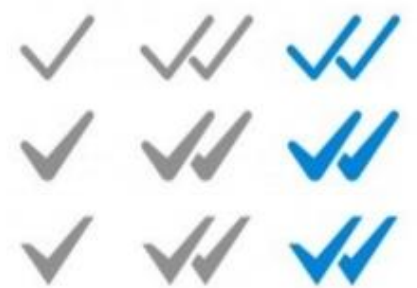

\section{DELIVERED}

Program membawa manfaat/ekspektasi kualitas yang ditargetkan.<smiles>C1CC2CCCC2C1</smiles>

Kualitas belajar murid meningkat.

"Kita harus mencari sebuah model baru, cara baru, nilainilai baru dalam mencari solusi dari setiap masalah dengan inovasi-inovasi. Dan kita semuanya harus mau dan akan kita paksa untuk mau. Kita harus meninggalkan cara-cara lama, pola-pola lama, baik dalam mengelola organisasi, baik dalam mengelola lembaga, maupun dalam mengelola pemerintahan." 


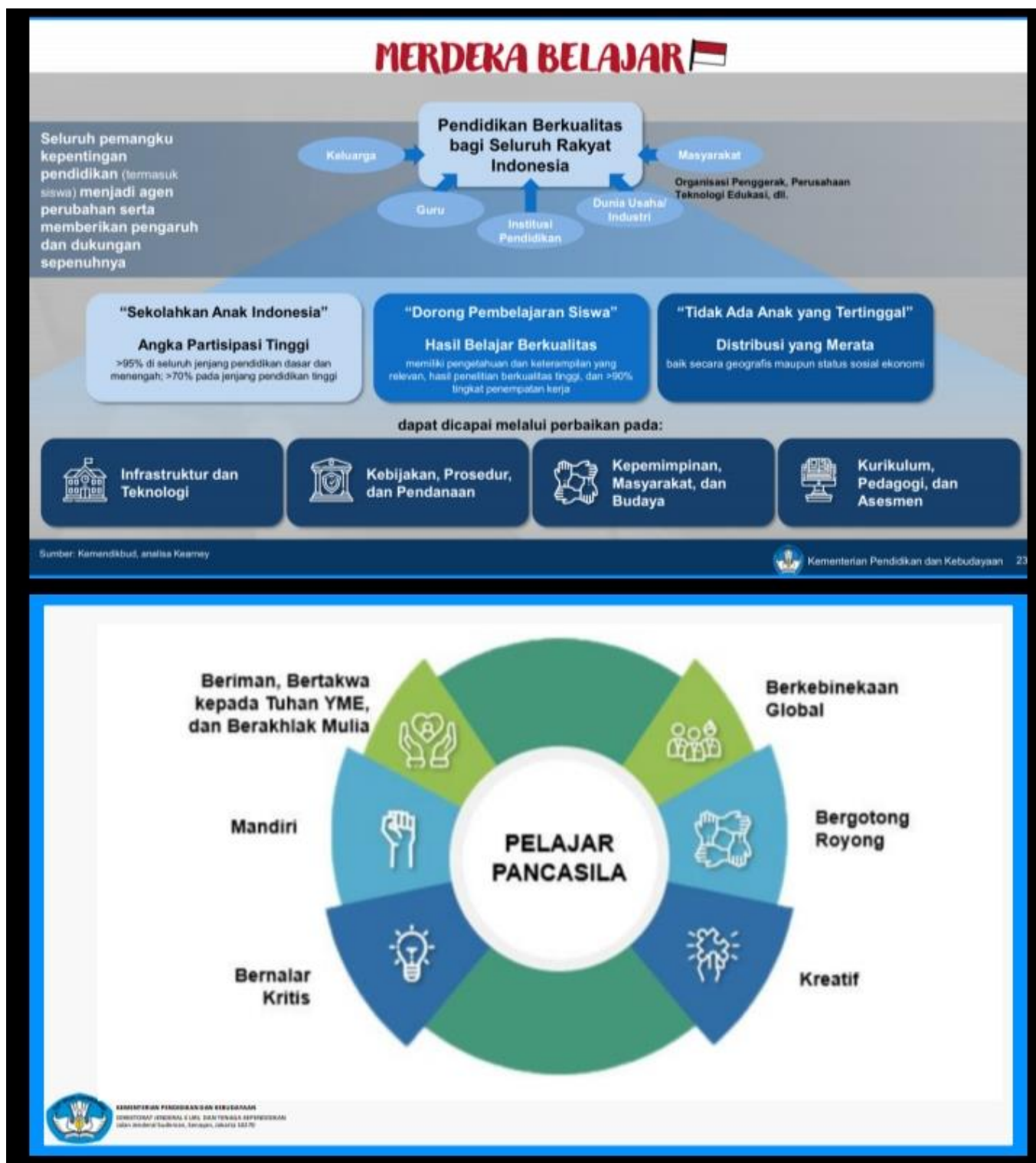

Pelajar Pancasila adalah perwujudan pelajar Indonesia sebagai pelajar sepanjang hayat yang memiliki kompetensi global dan berperilaku sesuai dengan nilai-nilai Pancasila, dengan enam ciri utama: beriman,bertakwa kepada Tuhan YME dan berakhlak mulia, berkebinekaan global, bergotong royong,mandiri, bernalar kritis, dan kreatif, 


\section{(1) Beriman, bertakwakepadaTuhanYME,dan berakhlakmulia}

Pelajar Indonesia yang beriman, bertakwa kepada Tuhan YME, dan berakhlak mulia adalahpelajar yang berakhlak dalam hubungannya dengan Tuhan Yang Maha Esa. Ia memahami ajaranagama dan kepercayaannya serta menerapkan pemahaman tersebut dalam kehidupannyasehari-hari. Ada lima elemen kunci beriman, bertakwa kepada Tuhan YME, dan berakhlak mulia:(a) akhlak beragama; (b) akhlak pribadi; (c) akhlak kepada manusia; (d) akhlak kepada alam; dan(e) akhlak bernegara.

\section{(2) Berkebinekaanglobal}

Pelajar Indonesia mempertahankan budaya luhur, lokalitas dan identitasnya, dan tetapberpikiran terbuka dalam berinteraksi dengan budaya lain, sehingga menumbuhkan rasa salingmenghargai dan kemungkinan terbentuknya budaya baru yang positif dan tidak bertentangandengan budaya luhur bangsa. Elemen kunci dari berkebinekaan global meliputi mengenal danmenghargai budaya, kemampuan komunikasi interkultural dalam berinteraksi dengan sesama,dan refleksi dan tanggung jawab terhadap pengalaman kebinekaan.

\section{(3) Bergotongroyong}

Pelajar Indonesia memiliki kemampuan bergotong royong, yaitu kemampuan untuk melakukankegiatan secara bersama-sama dengan suka rela agar kegiatan yang dikerjakan dapat berjalanlancar, mudah dan ringan. Elemen-elemen dari bergotong royong adalah kolaborasi,kepedulian, dan berbagi. 
SHEs: Conference Series 3 (2) (2020) 21 - 33

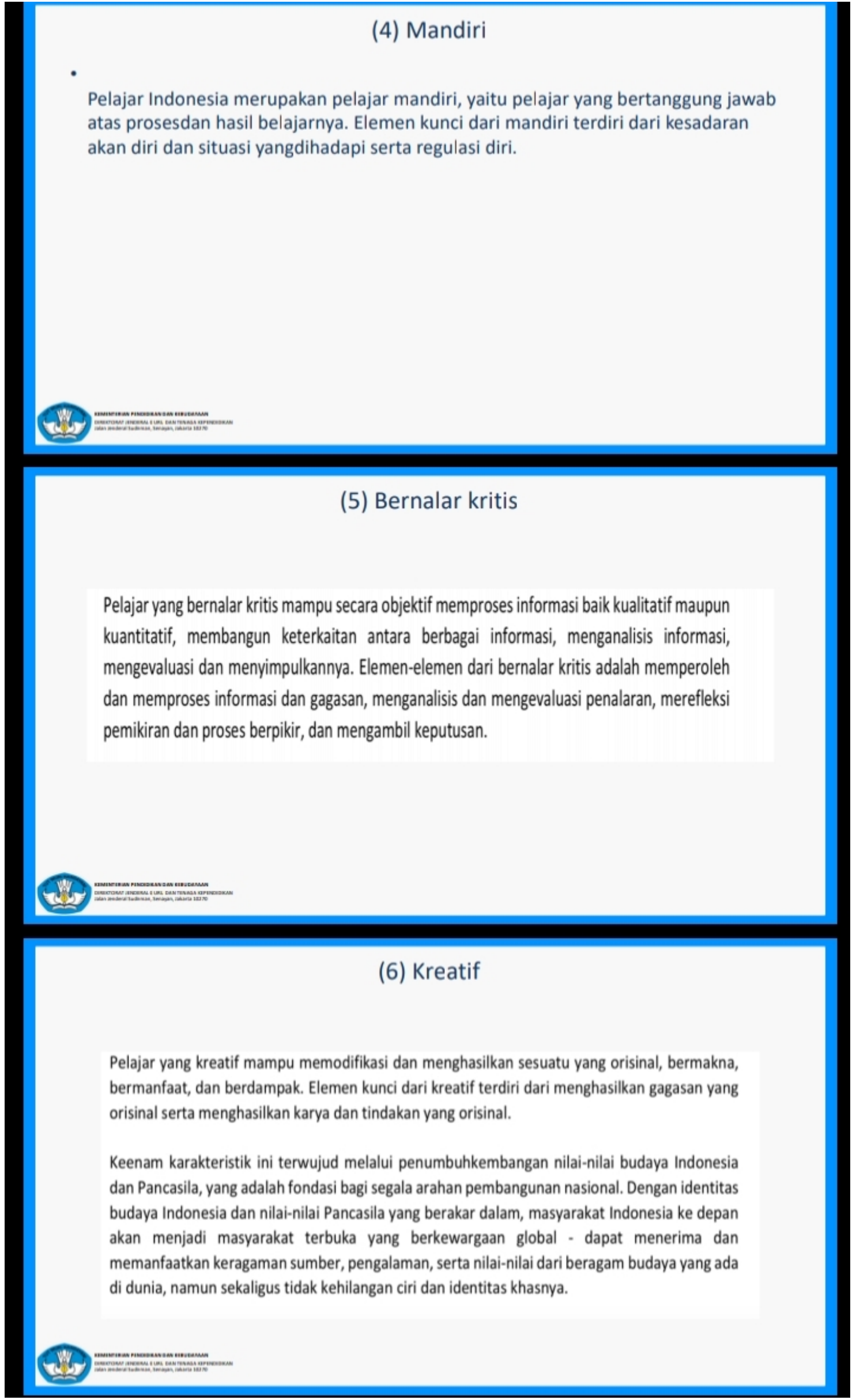


SHEs: Conference Series 3 (2) (2020) 21 - 33

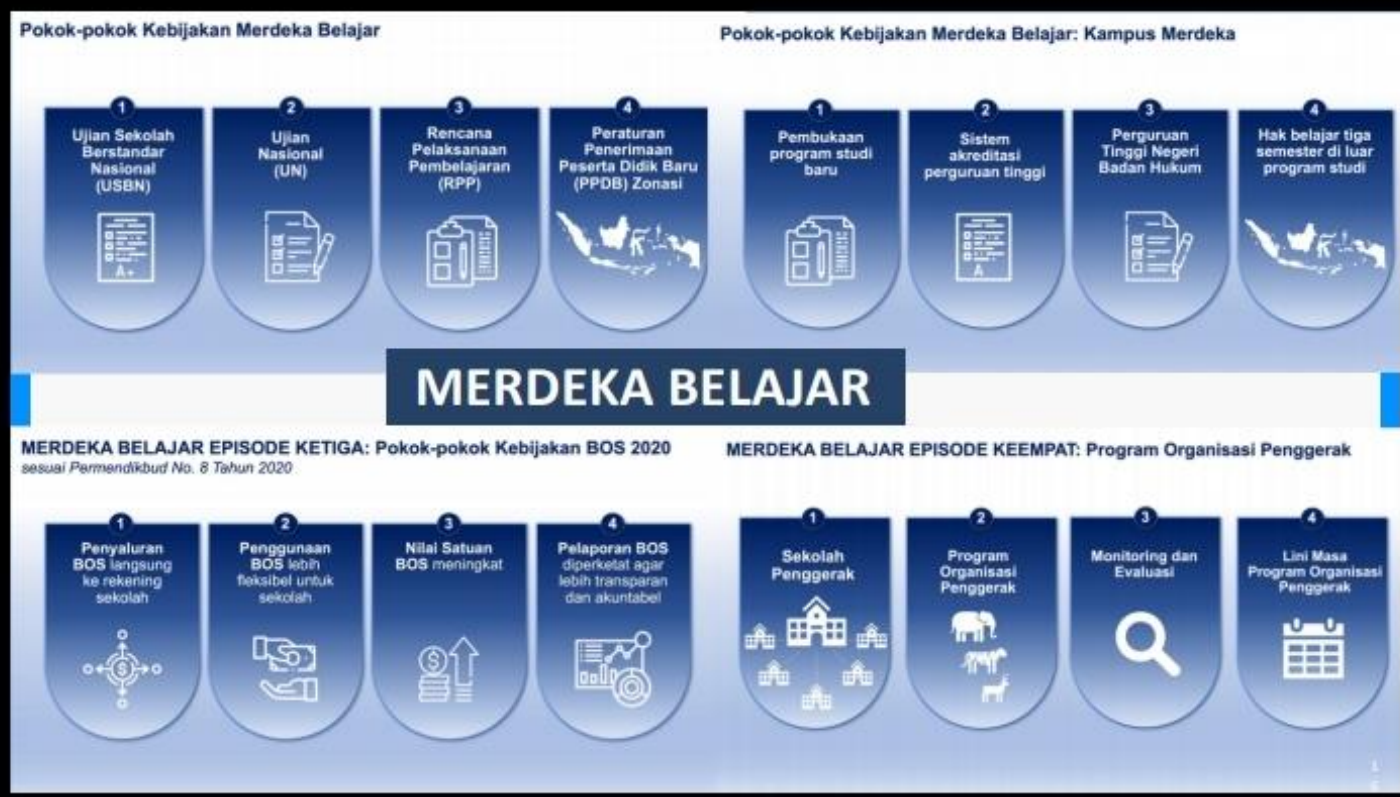

\section{KERANGKA UTAMA \\ TRANSFORMASI GTK}

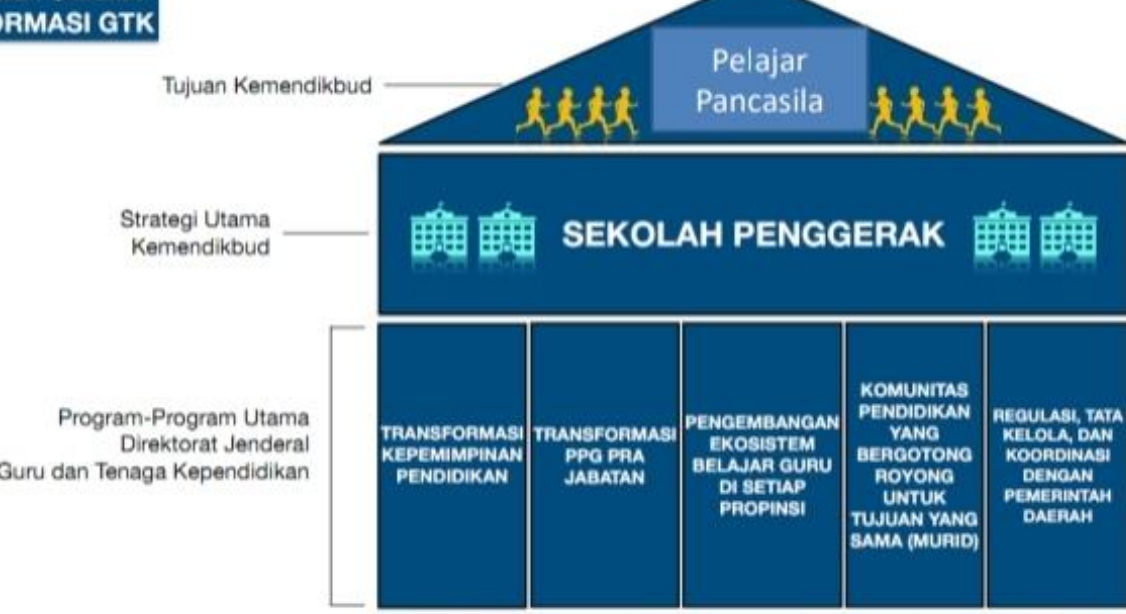

Program-Program Terkait

KEBIJAKAN TEKNOLOOI ASEsmeN KUAIKULUM

program Merdeka Belajar, guru jadi penggerak, Merdeka belajar artinya unit pendidikan yaitu sekolah, guru-guru dan peserta didiknya punya kebebasan. Kebebasan untuk berinovasi, kebebasan untuk belajar dengan mandiri dan kreatif.

Pada saat seluruh unit pendidikan diberikan kebebasan untuk melakukan inovasi maka perlu memasukkan kembali butir butir nilai pancasila melalui PBM yang kreatif dan mandiri 
- Dari sini layak kemudian guru yang menjadi penggerak untuk mengajak peserta didik menggali kembali nilai-nilai butir pancasila. Guru menjadi penggerak adalah guru yang mengutamakan murid dari apa pun, bahkan dari kariernya, mengutamakan murid dan pembelajaran murid. Karena itu mengambil tindakan-tindakan tanpa disuruh, diperintah, untuk melakukan yang terbaik.

Walau pun begitu, tetap saja instruksi diberikan oleh pemimpin kebijakan. Dalam hal ini Mendikbud yang menjadi ujung tombak progam Merdeka belajar harus kembali berinisiatif memasukkan butir-butir Pancasila pada program Merdeka belajar.

Prinsip Kebijakan Pendidikan di Masa Pandemi COVID-19

Kesehatan dan keselamatan peserta didik, pendidik, tenaga kependidikan, keluarga, dan masyarakat merupakan prioritas utama dalam menetapkan kebijakan pembelajaran. 


\section{Apakah New Normal?}

Istilah yang digunakan dalam berbagai keadaan lain untuk menyiratkan bahwa sesuatu yang tidak biasa atau belum pernah dilakukan sebelumnya. telah menjadi biasa. New normal bukanlah istilah baru, Istilah new normal muncul lebih dari dua dekade yang lalu, saat setelah krisis keuangan tahun 2007-2008 dan kemudian setelah resesi global pada tahun 2008-2012.

\section{SYARAT NEW NORMAL MENURUT WHO}

1. Negara yang akan menerapkan konsep new normal harus memiliki bukti bahwa penularan Covid-19 di wilayahnya telah bisa dikendalikan.

2. Sistem kesehatan yang ada sudah mampu melakukan identfikasi, isolasi, pengujian, pelacakan kontak, hingga melakukan karantina orang yang terinfeksi. Sistem kesehatan ini mencakup rumah sakit hingga peralatan medis.

3. Risiko wabah virus corona harus ditekan untuk wilayah atau tempat dengan kerentanan yang tinggi.

4. Langkah-langkah pencegahan di lingkungan kerja Langkahlangkah pencegahan ini meliputi penerapan jaga jarak fisik, ketersediaan fasilitas cuci tangan, dan penggunaan masker

5. Risiko terhadap kasus dari pembawa virus yang masuk ke suatu wilayah harus bisa dikendalikan.

6. Masyarakat harus diberikan kesempatan untuk memberi masukan, berpendapat dan dilibatkan dalam proses masa transisi menuju new normal.

\section{Panduan new normal dari Kemenkes untuk mencegah penularan} COVID-19 di tempat kerja.

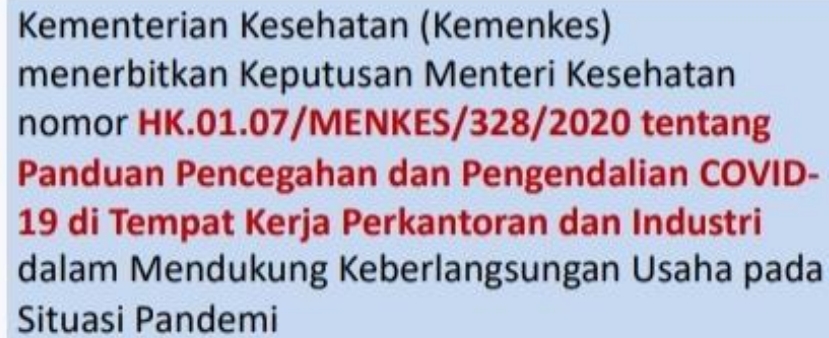




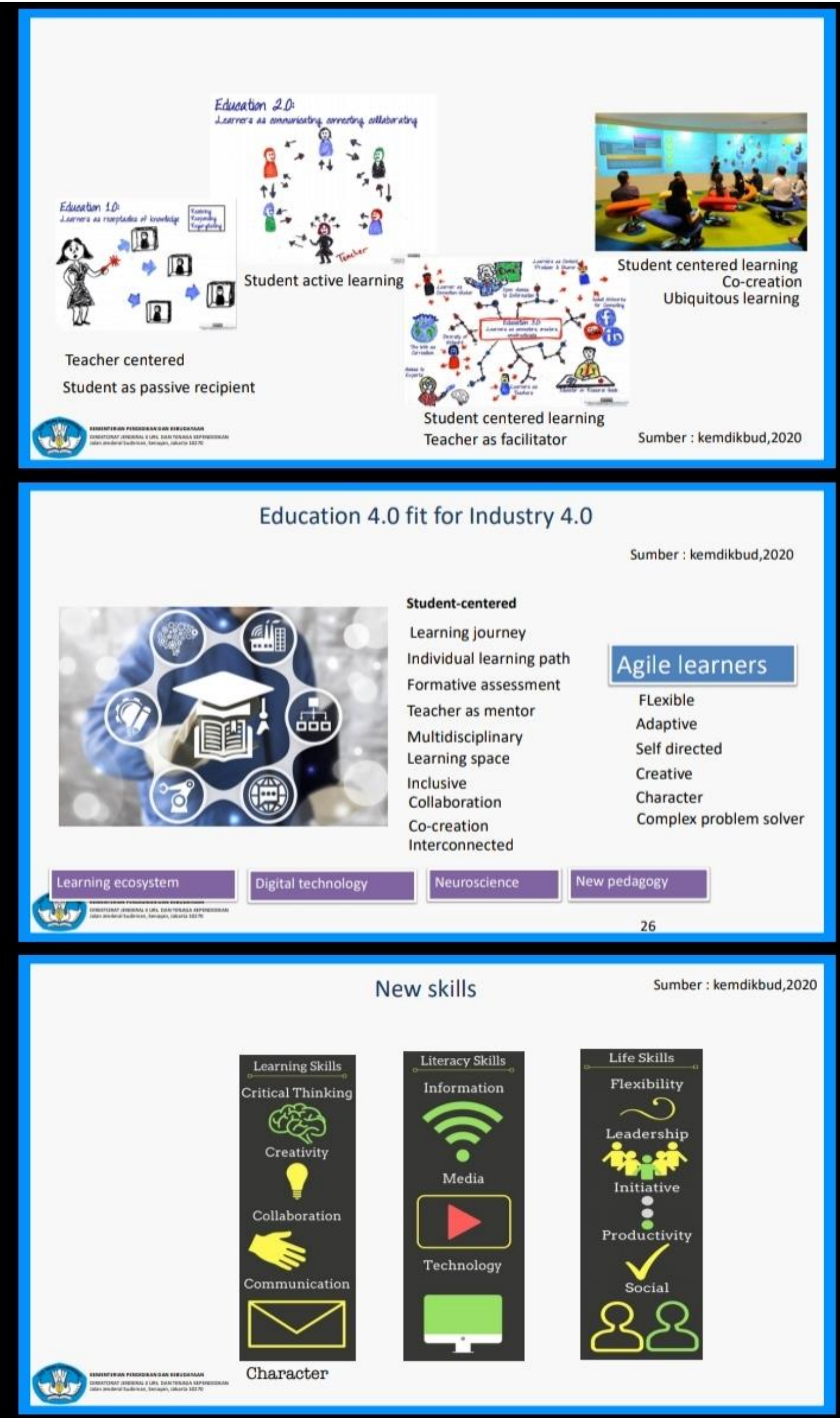


- Education 4.0 berbagai cara untuk mengintegrasikan teknologi di era Industrial Revolution 4.0 baik secara fisik maupun tidak ke dalam pembelajaran.

- "bisakah dosen melakukan?" dalam Masa dan pasca Pandemi?

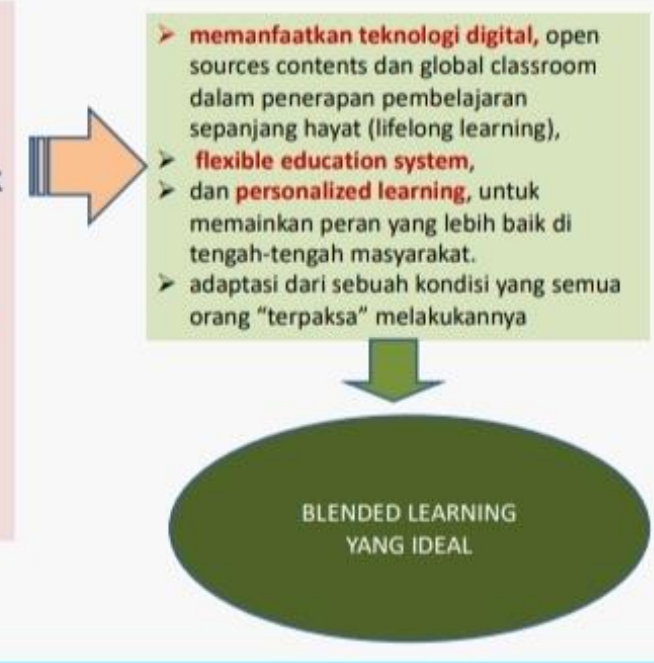

\section{Taxonomy Blended Learning}

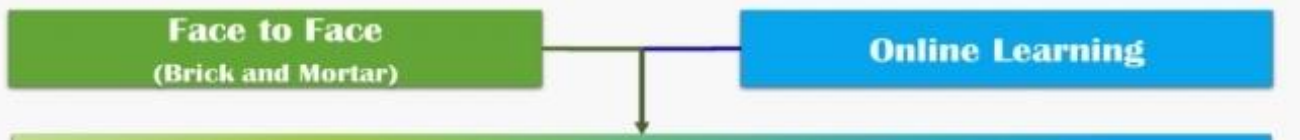

\section{Blended Learning}

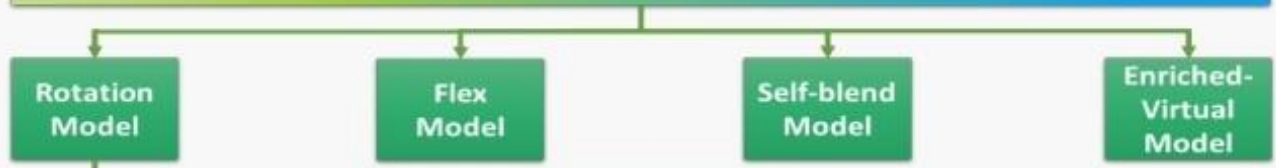

\section{Flipped-Classroom Model}

Station-Rotation Model

Lab-Rotation Model

Individual-Rotation Model

\section{Syarat Blended learning yang berkualitas}

1. dosen dan mahasiswa harus meningkatkan keterampilan internet dan literasi computer

2. Menentukan kembali capaian pembelajaran(tujuan pembelajaran) yaitu : penjajaran konstruktif (constructive aligment) ulang terhadap keselarasan tiga komponen Outcome Based Education (OBE), yakni (1) capaian pembelajaran, (2) aktivitas pembelajaran, dan (3) metode asesmen yang telah disusun dalam Rencana Pelaksanaan Pembelajaran RPP dan RPS

3. dosen harus menjamin kesiapan (readiness) materi pembelajaran dengan perspektif Belajar mandiri dalam format digital sedemikian rupa sehingga peserta didik mudah memahami materi pembelajaran, terutama jika diberikan secara luring

4. Tentukan durasi setiap unit pembelajaran

5. Asesmen dalam bentuk kuis dan tugas mandiri harus siap

6. sekolah harus mempersiapkan infrastruktur yang cukup

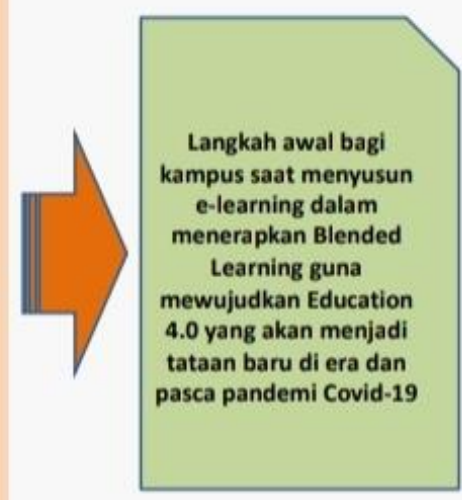




\section{METODE DAN MEDIA PELAKSANAAN}

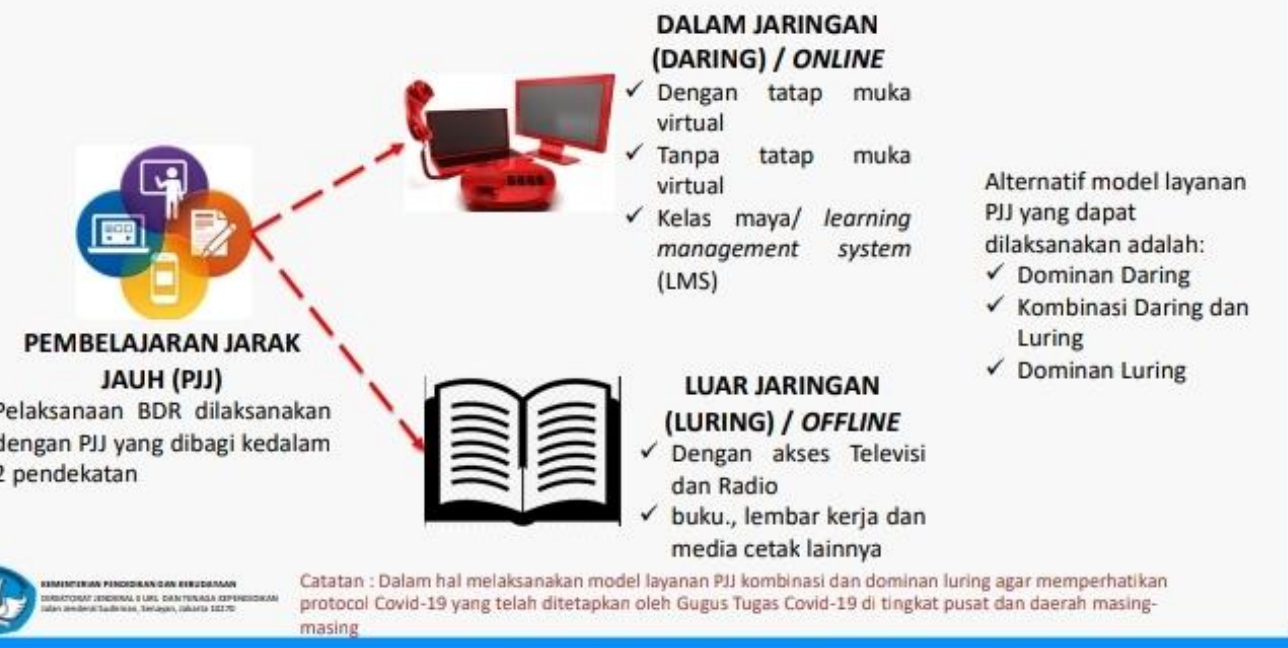

- berbagai cara untuk mengintegrasikan teknologi di baik secara fisik maupun tidak ke dalam pembelajaran.

- "bisakah kita melakukan?" dalam Masa dan pasca Pandemi?

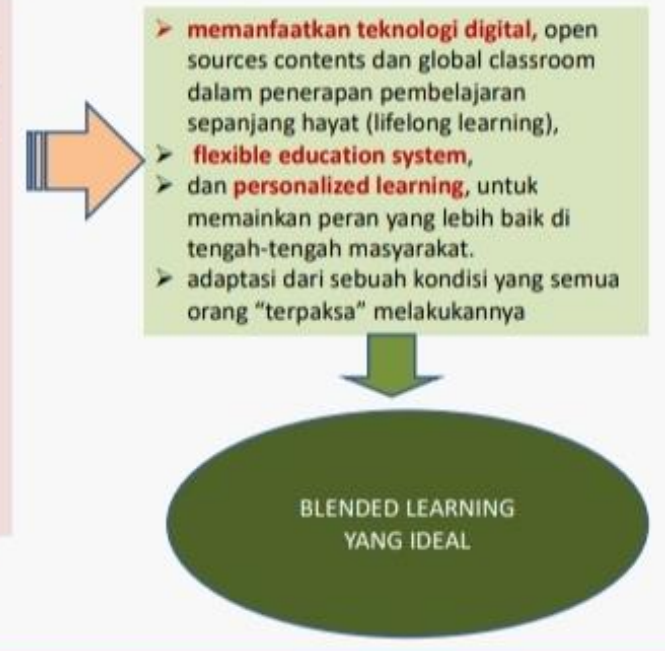

\section{Syarat Blended learning yang berkualitas}

1. guru dan siswa harus meningkatkan keterampilan internet dan literasi computer

2. Menentukan kembali capaian pembelajaran(tujuan pembelajaran) yaitu : penjajaran konstruktif (constructive aligment) ulang terhadap keselarasan tiga komponen Outcome Based Education (OBE), yakni (1) capaian pembelajaran, (2) aktivitas pembelajaran, dan (3) metode asesmen yang telah disusun dalam Rencana Pembelajaran RPP

3. guru harus menjamin kesiapan (readiness) materi pembelajaran dengan perspektif Belajar mandiri dalam format digital sedemikian rupa sehingga peserta didik mudah memahami materi pembelajaran, terutama jika diberikan secara luring

4. Tentukan durasi setiap unit pembelajaran

5. Asesmen dalam bentuk kuis dan tugas mandiri harus siap

6. sekolah harus mempersiapkan infrastruktur dan bandwidth yang cukup

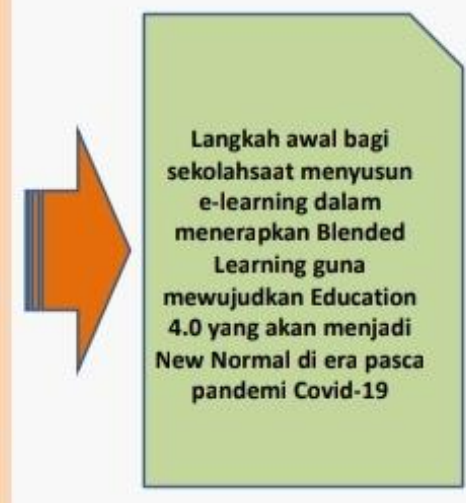


SHEs: Conference Series 3 (2) (2020) 21 - 33

\section{Tantangan}

Sumber: kemendikbud, 2020
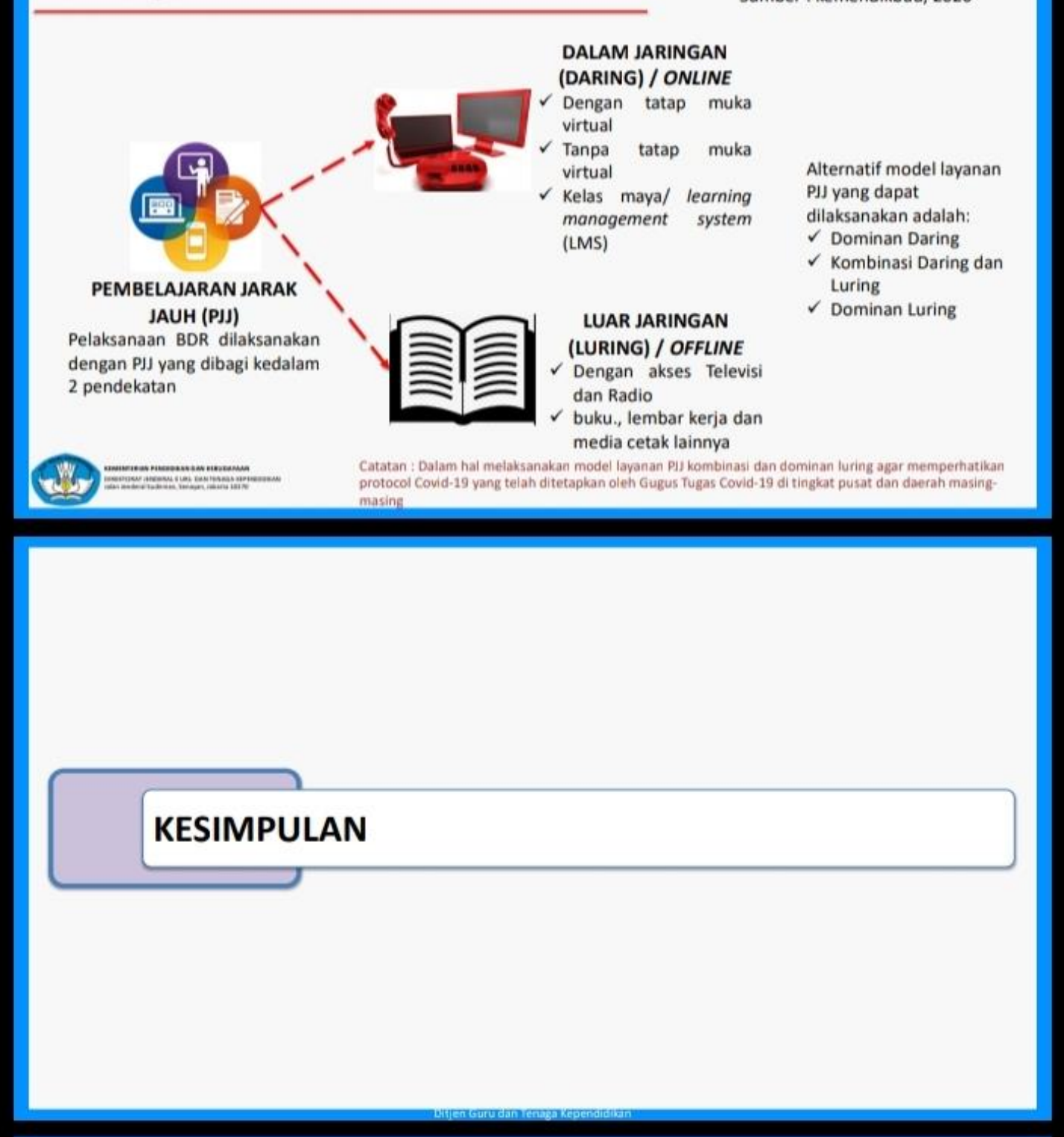

\section{KESIMPULAN}

- Hak peserta didik untuk mendapatkan Pendidikan yang layak harus tetap dapat dipenuhi selama masa darurat Covid-19

- Pandemi Covid-19, jangan menjadi kendala bagi tenaga pendidik untuk tetap melaksanakan tugasnya

- Tenaga pendidikan di tengah pandemi harus siap melakukan lompatan untuk melakukan transformasi pembelajaran menjadi pembelajaran daring bagi semua peserta didikm

- Tenaga pendidikan harus dapat belajar dengan cepat serta mampu beradaptasi pada kondisi yang berubah secara cepat, sehingga mampu menularkan semangat beradapatasi pada perubahan, mahasiswa, secara cepat dan akurat

- Berbagai moda daring dan luring yang disediakan oleh Kemendikbud atau yang tersedia secara gratis dan bebas dapat digunakan Tenaga pendidikan dalam melaksanakan pembelajaran masa pandemic Covid-19 mau pasca pandemic

- Seluruh ekosisitemsekolah harus bersiap memasuki new normal era dengan melakukan terobosan dan transformasi 
SHEs: Conference Series 3 (2) (2020) 21 - 33

\section{TERIMA KASIH}

Prof. Dr. Nunuk Suryani, M.Pd

nunuksuryani@lppks.kemdikbud.go.id

082221156262

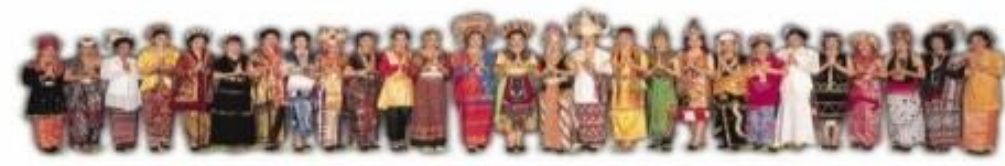

Direktorat Jenderal Guru Dan Tenaga Kependidikan

Kementerian Pendidikan dan Kebudayaan

Republik Indonesia 